\title{
Endoplasmic reticulum stress and apoptosis induced by manganese trigger $\alpha$-synuclein accumulation
}

\author{
Hyonok Yoon ${ }^{1,2}$, Geum Hwa Lee ${ }^{3}$, Bo Li ${ }^{3}$, Sunt Ah Park ${ }^{3}$, Seung-Jae Lee ${ }^{4}$, Han- \\ Jung Chae ${ }^{2 *}$ \\ ${ }^{1}$ College of Pharmacy and Research Institute of Pharmaceutical Sciences, Gyeongsang National University, Jinju, ${ }^{2}$ Department \\ of Life Style Medicine, Chonbuk National University, Jeonju, ${ }^{3}$ Department of Pharmacology and Cardiovascular Research \\ Institute, Medical School, Seoul, ${ }^{4}$ Department of Biomedical Sciences and Neuroscience Research Institute and College of \\ Medicine, Seoul National University, Seoul, Republic of Korea
}

${ }^{*}$ For correspondence: Email: hjchae@jbnu.ac.kr; Tel: +82-63-270-3092

\begin{abstract}
Purpose: To explore whether $\alpha$-synuclein aggregation is linked to endoplasmic reticulum (ER) stress and apoptosis induced by manganese (Mn) on CATH.a dopaminergic cell lines.

Methods: Western blot analysis for the expression of $78 \mathrm{kDa}$ glucose-regulated protein (GRP78),

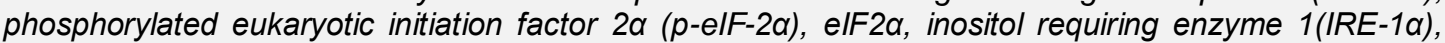
cleaved caspase-3, and C/EBP homologous protein (CHOP) was performed, including overexpression of recombinant adenovirus-mediated $\alpha$-synuclein on CATH.a dopaminergic cell line.

Results: It was observed that cell viability $(p<0.05)$ was significantly reduced by $250 \mu M$ exposed for 3 $h$ and 1,000 $\mu \mathrm{M}$ of $\mathrm{MnCl}_{2}$ exposed for $24 \mathrm{~h}$. The expression of p-elF-2a, IRE-1a, and GRP78 was especially induced by $1,000 \mu \mathrm{M}$ of $\mathrm{MnCl}_{2}$ exposed at 3,6 , and $12 \mathrm{~h}$, respectively $(p<0.05)$. Twenty four-hour exposure of $250 \mathrm{uM}$ of $\mathrm{MnCl}_{2}$ and the $3 \mathrm{~h}$ exposure of 1,000 uM of $\mathrm{MnCl}_{2}$ significantly induced CHOP, active caspase 3 and $\alpha$-synuclein expression $(p<0.05)$. a-Synuclein combined with recombinant adenoviral transduction increased GRP78, IRE-1a and elF2a, CHOP and caspase 3 expression at longer times and at higher concentrations of manganese exposure on CATH.a dopaminergic cells.

Conclusion: Based on these findings, $\mathrm{Mn}$ is a risk factor for diseases associated with $\alpha$-synuclein accumulation. Furthermore, a-synuclein accumulation is associated with apoptosis via ER stress induced by $\mathrm{Mn}$.
\end{abstract}

Keywords: Manganese (Mn), a- Synuclein, Endoplasmic reticulum (ER) stress, Apoptosis

\begin{abstract}
This is an Open Access article that uses a funding model which does not charge readers or their institutions for access and distributed under the terms of the Creative Commons Attribution License (http://creativecommons.org/licenses/by/4.0) and the Budapest Open Access Initiative (http://www.budapestopenaccessinitiative.org/read), which permit unrestricted use, distribution, and reproduction in any medium, provided the original work is properly credited.

Tropical Journal of Pharmaceutical Research is indexed by Science Citation Index (SciSearch), Scopus, International Pharmaceutical Abstract, Chemical Abstracts, Embase, Index Copernicus, EBSCO, African Index Medicus, JournalSeek, Journal Citation Reports/Science Edition, Directory of Open Access Journals (DOAJ), African Journal Online, Bioline International, Open-J-Gate and Pharmacy Abstracts
\end{abstract}

\section{INTRODUCTION}

Neurodegenerative diseases result in the progressive loss of structure or function of neurons, including the death of neurons. They are caused by genetic mutation or by extracellularly excreted proteins such as amyloid$\beta$, or by damage to the membranes of organelles by monomeric or oligomeric proteins such as $\alpha$ synuclein [1], or by aggregation of misfolded proteins [2]. 
a-Synuclein is a protein that is expressed in abundant amounts in the human brain during human fetal development[3]. It is found at the tips of neurons in the presynaptic terminals which release neurotransmitters from synaptic vesicles [4]. In experiments with mouse models for learning and working memory, $\alpha$-synuclein function has been reported as potentially playing an important role in the development of cognitive function [5]. This means that $\alpha$-synuclein may be strongly related to the progressing of Alzheimer's disease (AD). It has also been reported that $\alpha$ synuclein precipitates predominantly in the cytoplasm of neurons in Lewy-body disorders, and has a critical role in maintaining supply of synaptic vesicles in presynaptic terminals [6] as well as regulating dopamine, a neurotransmitter related to voluntary movements [7]. Movement disorders such as rigidity, tremor, bradykinesia, postural instability and dyskinesia are usually classified as related to problems in Parkinson's disease (PD) [8].

One of the risk factors for $P D$, is associated with exposure to heavy metals like manganese (Mn) [9]. Appropriate amount of $\mathrm{Mn}$ can play critical roles in growth, metabolism, and antioxidant system in the human body. But excessive Mn causes $\mathrm{Mn}$ toxicity that induces manganism, the symptom of neurodegenerative disorders such as motor impairment and dementia. How neurodegenerative disorders are related to $\mathrm{Mn}$ toxicity is not well known.

In our study, the mechanism of Mn toxicity and the relationship between $\alpha$-synuclein aggregation as well as ER stress and apoptosis, were investigated.

\section{EXPERIMENTAL}

\section{Materials}

Roswell Park Memoria Institute (RPMI) 1640 medium was purchased from Grand Island Biological Company (GIBCO, New York, USA). Fetal bovine serum (FBS), trypsin, and other tissue culture reagents were purchased from Life Technologies Inc. (Gaithersburg, MD, U.S.A). $\mathrm{MnCl}_{2}$ and other reagents were purchased from either Sigma or Aldrich (St. Louis, MO, U.S.A) and stored according to the manufacturer's instructions. All reagents were of analytical grade, and plastic wares such as cell culture dishes were obtained from Falcon Inc. (Franklin, NJ, U.S.A). $78 \mathrm{kDa}$ glucose-regulated protein (GRP78), C/EBP homologous protein (CHOP), Bactin were purchased from Santa Cruz Biotechnology (Santa Cruz, CA, U.S.A). Phosphorylated eukaryotic initiation factor $2 \alpha(p-$ elF-2 $\alpha$ ) was provided by Cell Signaling
Technology Inc. (Danvers, MA, U.S.A). CATH.a (mouse neuroblastoma) cells were obtained from the American Type Culture Collections (Manassas, VA, USA).

\section{Cell culture and cell viability}

CATH.a (mouse neuroblastoma) cells were maintained at $37^{\circ} \mathrm{C}$ in a humidified atmosphere with $5 \% \mathrm{CO}_{2}$. The cell lines were cultured in RPMI 1640 medium which supplemented with 8 $\%$ horse serum, 4 \% FBS, $100 \mathrm{U} / \mathrm{mL}$ penicillin, $100 \mu \mathrm{g} / \mathrm{mL}$ streptomycin and $2 \mathrm{mM}$ L-glutamine. Cell viability was assessed with the trypan blue exclusion assay and calculated by dividing the non-stained (viable) cell count by the total cell count $\left(3 \times 10^{6}\right)$.

\section{Western blot analysis}

Proteins extracted from CATH.a cells were analyzed by Western blot as described in the previous method $[10,11]$. Cells were lysed in RIPA buffer (10 mM Tris pH 7.4, $150 \mathrm{mM} \mathrm{NaCl}$, $1 \%$ Triton $\mathrm{X}-100,1 \%$ sodium deoxycholate, 0.1 $\%$ sodium dodecyl sulfate, $1 \mathrm{mM}$ phosphatase inhibitor cocktail, $1 \mathrm{mM}$ protease inhibitor cocktail) left on ice for $30 \mathrm{~min}$. Proteins were extracted and they were separated on 7-12\% sodium dodecyl sulfate polyacrylamide gel electrophoresis (SDS-PAGE) gels and electro transferred to $0.22 \mu \mathrm{m}$ polyvinylidene difluoride (PVDF) membrane using a Bio-Rad mini-transfer tank. Then, membranes were probed with the primary antibodies: anti-cleaved Caspase-3, antip-elF2 $\alpha$, anti-elF2 $\alpha$ (Cell Signalling, Danvers, MA), anti-IRE-1 $\alpha$ (Abcam, Cambridge, UK) antiGRP78, anti-CHOP, anti- $\beta$-actin and anti- $\alpha-$ synuclein (Santa Cruz Biotechnology, Santa Cruz, CA). The antibodies were recognized using secondary antibodies of anti-mouse or anti-rabbit $\operatorname{lgG}_{1}$ linked to horseradish peroxidase at room temperature for $60 \mathrm{~min}$. The immune reactive bands were visualized using an enhanced chemiluminescence (ECL) kit (Amersham, Buckinghamshire, UK) and exposed to LAS 3000 (Fujifilm, Japan).

\section{Expression of $\alpha$-synuclein and induction of aggregation}

For $\alpha$-synuclein expression in CATH.a. cells, a recombinant adenoviral vector containing human a-synuclein cDNA (ad.a-synu), and recombinant adenoviral vector containing $\beta$-galactosidase (BD Biosciences, USA) were used as previously described [12]. Recombinant adenoviral vector containing $\beta$-galactosidase was described as adenoviral non-specific vector (ad.NS) for $\alpha$ synuclein. Adenoviruses kindly were provided by 
Dr. S.J. Lee. CATH.a. cells were infected with ad.a-synu and ad.NS for 3 days. After infection, cells were incubated in a humidified, $5 \% \mathrm{CO}_{2}$ atmosphere at $37^{\circ} \mathrm{C}$. Incubation with adenovirus continued for $16 \mathrm{~h} . \mathrm{MnCl}_{2}$ was treated at a concentration of $1,000 \mu \mathrm{M}$ for 0 (control), 3, 6, $12,24 \mathrm{~h}$. It was treated with concentration of 0 (control), $100,250,500,1,000 \mu \mathrm{M}$ of $\mathrm{MnCl}_{2}$ for $24 \mathrm{~h}$ for induction of $\alpha$-synuclein aggregation at the same day when the infected cells were split.

\section{Protein determination}

Protein concentrations of the homogenates were determined using the method of with bovine serum albumin (BSA) as standard.

\section{Statistical analysis}

All the data were expressed as mean \pm standard error (SE) and one-way analysis of variance (ANOVA) followed by Dunnett's test using SPSS software (version 16, Chicago. IL. USA). The criterion for significance $(p<0.05)$ was set as stated in Figure legends.

\section{RESULTS}

\section{Cell toxicity}

Cells were treated with $1,000 \mu \mathrm{M}$ of $\mathrm{MnCl}_{2}$ for different durations $(3,6,12$ and $24 \mathrm{~h})$ and with different doses: $100,250,500$ and $1,000 \mu \mathrm{M}$ of $\mathrm{MnCl}_{2}$ for $24 \mathrm{~h}$. The longer the time and the higher the dose of exposure of $\mathrm{MnCl}_{2}$ induced less cell viability (Figure 1) and more toxicity.
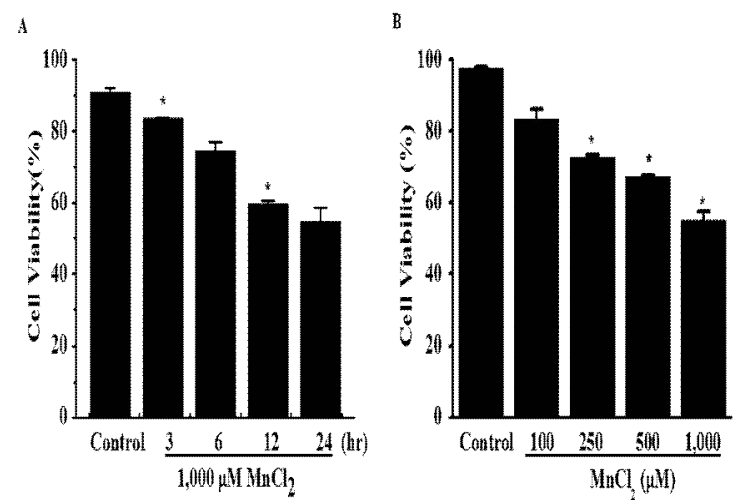

Figure 1: Effects of different time and different concentration of $\mathrm{MnCl}_{2}$ exposure. Cell viability was accessed by tryphan blue assay. (A) Cells were treated with $1,000 \mu \mathrm{M}$ of $\mathrm{MnCl}_{2}$ for $3,6,12,24 \mathrm{~h}$ and the cell viability was assessed by trypan blue assay.(B) Cells were treated 100, 250, 500, 1,000 $\mu \mathrm{M}$ of $\mathrm{MnCl}_{2}$ for $24 \mathrm{~h}$ and the cell viability was assessed by trypan blue assay. Data represent mean $\pm \mathrm{SE}(\mathrm{n}=$ 3 ); ${ }^{*} p<0.05$ significantly different from control group

\section{ER stress is dependent on time and dose of Mn exposure}

ER stress markers, GRP 78, IRE-1 $\alpha$ and $p$ elF2 $\alpha$, were used in the experiment to determine whether ER stress was affected by the time and dose of $\mathrm{MnCl}_{2}$ exposure in CATH.a cell line. The longer the exposure time of $\mathrm{MnCl}_{2}$, the more GRP 78 expressed. Exposure of $\mathrm{MnCl}_{2}$ for more than $6 \mathrm{~h}$ induced significant expression of IRE-1 $\alpha$ and exposure of $\mathrm{MnCl}_{2}$ for more than $3 \mathrm{~h}$ induced remarkable expression of $p$-elF $2 \alpha$ (Figure $2 \mathrm{~A}$ ).

GRP 78 was significantly expressed at exposure of $\mathrm{MnCl}_{2}$ over $500 \mu \mathrm{M}$, IRE-1a was remarkably expressed at exposure of $\mathrm{MnCl}_{2}$ of over $250 \mu \mathrm{M}$, and p-elF2 $\alpha$ expressed at $1,000 \mu \mathrm{M}$ of $\mathrm{MnCl}_{2}$ exposure (Figure $2 \mathrm{~B}$ ).

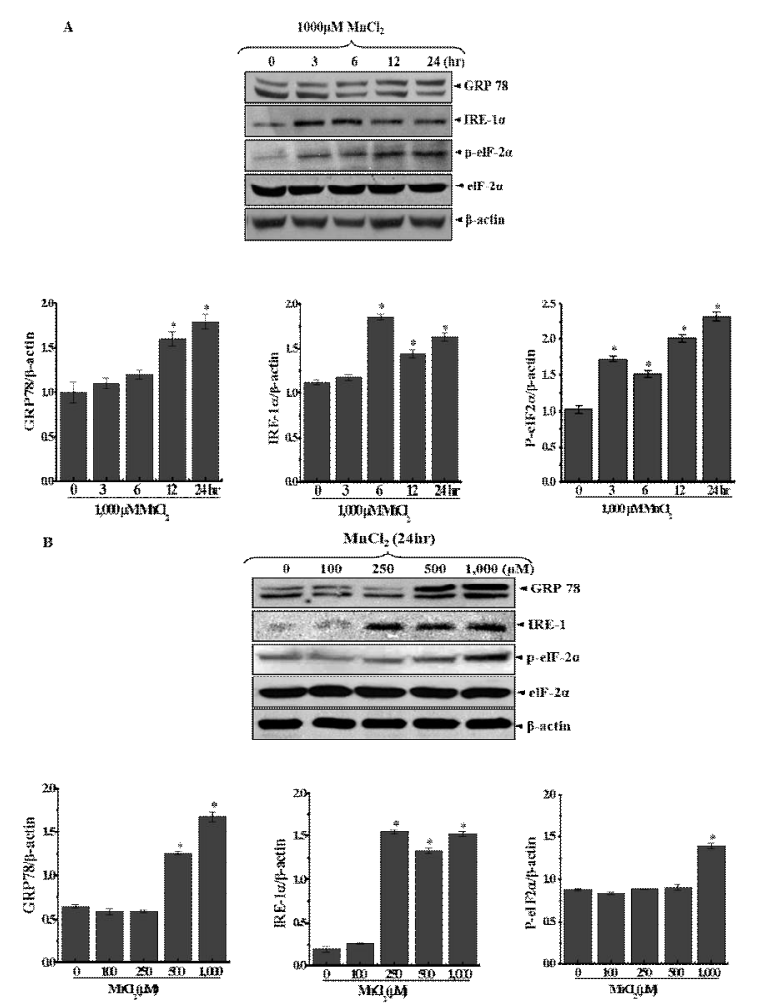

Figure 2: Exposure time and dose to $\mathrm{MnCl}_{2}$ were associated with ER stress expression. (A)Cells treated with $1,000 \mu \mathrm{M}$ of $\mathrm{MnCl}_{2}$ for 3, 6, 12 and $24 \mathrm{~h}$ were lysed. SDS-PAGE and immunoblotting were performed with anti-GRP78, IRE-1, p-elF-2 $\alpha$, elF-2 $\alpha$, and $\beta$-actin. (B)Cells treated with 100, 250, 500, 1,000 $\mu \mathrm{M}$ of $\mathrm{MnCl}_{2}$ for $24 \mathrm{~h}$ were lysed. SDS-PAGE and immunoblotting were performed with anti-GRP78, IRE1 , p-elF-2 $\alpha$, elF- $2 \alpha$, and $\beta$-actin. Data represent mean \pm SE $(n=3) ;{ }^{*} p<0.05$ significantly different from control group (0 denotes control)

\section{Apoptosis is regulated by the time and the dose of $\mathrm{MnCl}_{2}$ exposure}

CHOP of the apoptotic markers gradually increased expression when cells exposed to 
$1,000 \mathrm{uM}$ of $\mathrm{Mn}$ at over $3 \mathrm{~h}$, and showed a significant expression from over $250 \mu \mathrm{M}$ of $\mathrm{Mn}$ for 24 hours exposure. Another of the apoptotic markers, caspase 3 was time and dose dependent (Figure 3), suggesting that Mn causes apoptosis.

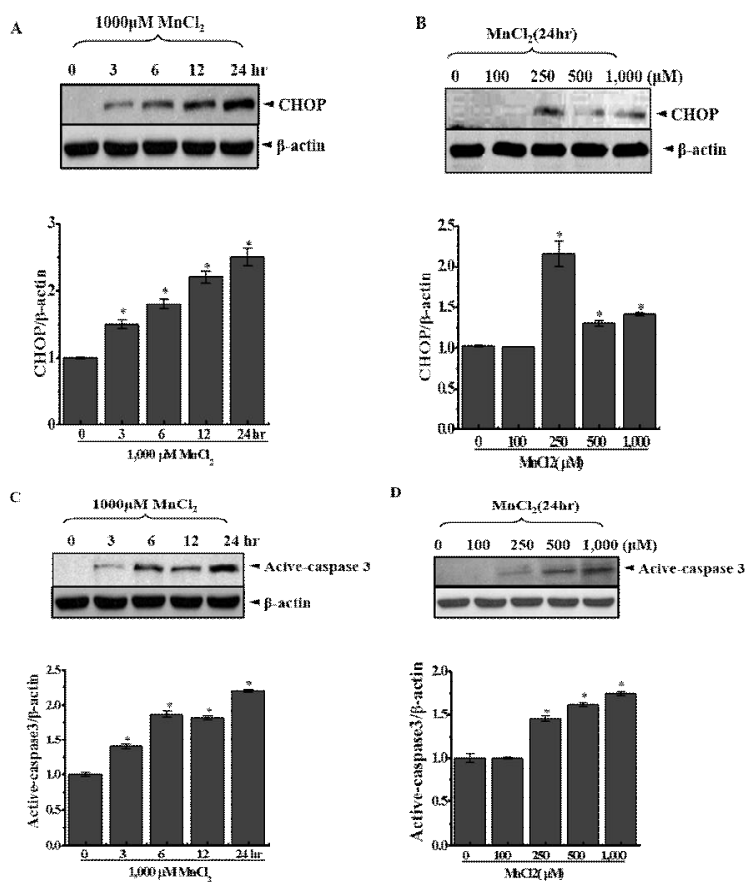

Figure 3: Exposure of $\mathrm{MnCl}_{2}$ induced apoptosis. (A) Cells treated with $1,000 \mu \mathrm{M}$ of $\mathrm{MnCl}_{2}$ for $3,6,12$ and $24 \mathrm{~h}$ were lysed. SDS-PAGE and immunoblotting were performed with anti-CHOP and $\beta$-actin. (B) Cells treated with $100,250,500,1,000 \mu \mathrm{M}$ of $\mathrm{MnCl} 2$ for $24 \mathrm{~h}$ were lysed. SDS-PAGE and immunoblotting were performed with anti-CHOP and $\beta$-actin. (C) Cells treated with $1,000 \mu \mathrm{M}$ of $\mathrm{MnCl}_{2}$ for $3,6,12$ and $24 \mathrm{~h}$ were lysed. SDS-PAGE and immunoblotting were performed with anti-Active caspase 3 and $\beta$-actin. (D) Cells treated with $100,250,500,1,000 \mu \mathrm{M}$ of $\mathrm{MnCl}_{2}$ for $24 \mathrm{~h}$ were lysed. SDS-PAGE and immunoblotting were performed with anti-active caspase 3 and $\beta$-actin. Data represent mean $\pm S E(n=3) ;{ }^{*} p<0.05$ significantly different from control group (0 denotes control)

\section{More a-synuclein was expressed by longer time and higher dose of $\mathrm{MnCl}_{2}$ exposure}

To determine whether $\mathrm{MnCl}_{2}$ can cause the accumulation of $\alpha$-synuclein, western blotting with $\alpha$ - synuclein protein was performed. Interestingly, expression of a-synuclein was dependent on the time and the dose of $\mathrm{MnCl}_{2}$ exposure in the CATH.a cell (Figure 4 and 5). As the concentration of $\mathrm{MnCl}_{2}$ increased by 100 , 250 and $500 \mu \mathrm{M}$, the amount of $\alpha$-synuclein expression gradually increased and it was increased significantly at $1,000 \mu \mathrm{M}$ of $\mathrm{MnCl}_{2}$. The data showed the longer the exposure time to $\mathrm{Mn}$, the more accumulation of $\alpha$-synuclein (Figure 4).
a-Synuclein also showed more oligomerization with increasing time and concentration of $\mathrm{Mn}$ in cells treated with recombinant adenovirus vector containing a-synuclein cDNA (Figure 5).
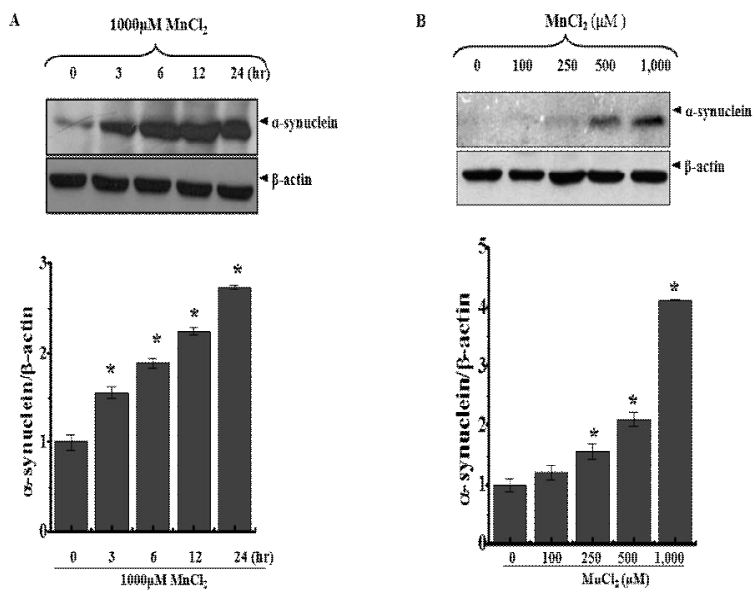

Figure 4: Effect of $\mathrm{MnCl}_{2}$ on endogenous $\alpha$-synuclein levels in CATH. a cells. (A) Cells treated with 1,000 $\mu \mathrm{M}$ of $\mathrm{MnCl}_{2}$ for 3, 6, 12 and $24 \mathrm{~h}$ were lysed. SDSPAGE and immunoblotting were performed with anti$\alpha$-synuclein and $\beta$-actin. (B) Cells treated with 100, $250,500,1,000 \mu \mathrm{M}$ of $\mathrm{MnCl}_{2}$ for $24 \mathrm{~h}$ were lysed. SDS-PAGE and immunoblotting were performed with anti- $\alpha$-synuclein and $\beta$-actin. Data represent mean \pm SE $(\mathrm{n}=3) ;{ }^{*} p<0.05$ significantly different from control group ( 0 denotes control)

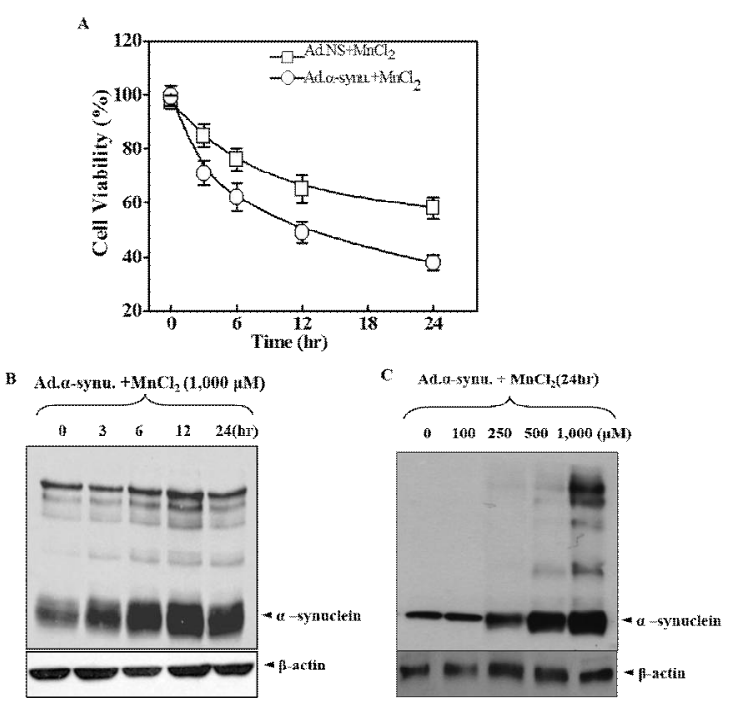

Figure 5: Effects of $\mathrm{MnCl}_{2}$ and $\alpha$-synuclein on recombinant adenoviral vector with $\alpha$-synuclein cDNA (Ad. $\alpha$-synu) and without $\alpha$-synuclein cDNA (Ad. NS) (A) Cell viability on CATH.a cells. Cell viability was assessed using trypan blue. (B) a-Synuclein oligomerization after $0,3,6,12$ and $24 \mathrm{~h}$ exposure of $1,000 \mu \mathrm{M}$ of $\mathrm{MnCl}_{2}$ on recombinant adenoviral vector with $\alpha$-synuclein cDNA (Ad. $\alpha$-synu). (C) $\alpha$-Synuclein oligomerization after $24 \mathrm{~h}$ exposure of $0,100,250,500$ and $1,000 \mu \mathrm{M}$ of $\mathrm{MnCl}_{2}$ on recombinant adenoviral vector with $\alpha$-synuclein cDNA (Ad. $\alpha$-synu)

Trop J Pharm Res, August 2018; 17(8): 1500 


\section{a-Synuclein expression is associated with apoptosis via ER Stress}

ER stress markers such as GRP 78, IRE-1, pelF2a, elF2 were more expressed in the cells treated with the cDNA recombinant adenovirus vector containing $\alpha$ - synuclein than the cells treated with the recombinant adenovirus vector containing $\beta$ - galactosidase (non- specific cells, ad.NS) when cells exposed to Mn. CHOP and active caspase 3 expressed more on the cells of recombinant adenoviral vector with $\alpha$-synuclein cDNA than non-specific cells. These data suggested that apoptosis induced by $\mathrm{Mn}$ was significantly declined under non-specific cells of a-synuclein cDNA. Apoptosis increased in cells treated by recombinant adenoviral vector with $\alpha$ synuclein cDNA. These data implied that $\alpha$ synuclein overexpression could play an important role in $\mathrm{Mn}$ induced ER stress and apoptosis (Figure 6).

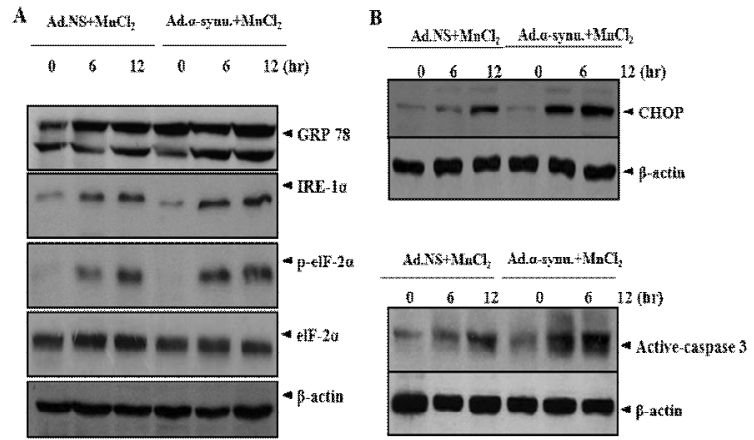

Figure 6: Characterization of $\mathrm{MnCl}_{2}$ and $\alpha$-synuclein on recombinant adenoviral vector with (Ad. a-synu) and without $\alpha$-synuclein cDNA (Ad.-NS). (A) Effect of ER stress markers on recombinant adenoviral vector with (Ad. $\alpha$-synu) and without $\alpha$-synuclein cDNA (Ad.NS). (B) Effect of apoptotic markers on recombinant adenoviral vector with (Ad. $\alpha$-synu) and without $\alpha$ synuclein cDNA (Ad.-NS). (Ad. $\alpha$-synu: recombinant adenovirus vector containing $a$-synuclein cDNA, Ad.NS: non-specific recombinant adenovirus vector)

\section{DISCUSSION}

Exposure to high Mn level leads progressive and irreversible symptoms such as rigidity, tremor, bradykinesia, postural instability, dyskinesia, cognitive disorder and neurologic damage [13]. The neuronal damage has been known to be associated with ER stress [11]. However, the exact mechanism of Mn-induced ER stress is not fully understood.

ER stress is activated by mutations in proteins, oxidative stress, calcium depletion, nutrient deprivation, altered glycosylation. And it triggers the unfolded protein response (UPR) [14]. When the UPR fails to restore ER homeostasis with prolonged ER stress, cell progresses from survival condition to apoptosis due to the activated UPR. The UPR is initiated by the activation of three molecular chaperones [15]: protein kinase RNA-like endoplasmic reticulum kinase (PERK), activating transcription factor 6

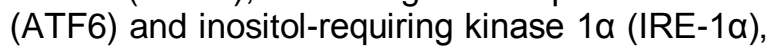
the mechanism of which is not yet fully clarified. However, $78 \mathrm{kDa}$ glucose regulated protein (GRP 78)/binding immunoglobulin protein (BiP) located in the lumen of the ER and it is one of the most widely accepted models for the recognition of unfolded proteins. It is an important component of the translocation [16].

In this study, it was observed that exposure to $\mathrm{MnCl}_{2}$ increased the expression of GRP78, IRE$1 \alpha, p$-elF-2 $\alpha$ and elF- $2 \alpha$, and it suggests that ER stress plays a salient role in Mn induced toxicity (Figure 2). CCAAT/enhancer-binding protein homologous protein (CHOP) is a pro-apoptotic protein and stimulates cell death by promoting protein synthesis and oxidation in the stressed ER [17]. Caspase-3 is an active effector caspase of the cysteine aspartic acid protease protein family [18] and is activated through proteolytic cleavage in the apoptotic cell death by intrinsic (mitochondria) and extrinsic (death ligand) pathways [19]. The extrinsic activation of caspase- 3 plays a salient role in the caspase cascade characteristic of the apoptotic pathway [20]. It was further observed that the longer exposure time and the higher exposure concentration to $\mathrm{Mn}$, the more expression of $\mathrm{CHOP}$ and caspase- 3 increased and it suggested that ER stress induced by Mn elicits apoptosis in dopaminergic models (Figure 3 ).

Many studies have been conducted to identify whether the mechanism of $\alpha$-synuclein as well as the accumulation of $\alpha$-synuclein can have harmful or beneficial effects. However, the exact function of $\alpha$-synuclein has not been fully demonstrated.

While previous studies have been focused on the overexpression of $\alpha$-synuclein in various cell lines [21], our study is hypothesized that $\mathrm{Mn}$ can induce $\alpha$-synuclein directly expression, and that $\mathrm{Mn}$ and $\alpha$-synuclein are closely related to the development of PD. Recent research reported that overexpression of $\alpha$ - synuclein can activate ER stress through the PERK signaling pathway following apoptosis [22]. However, a-synuclein function on cell damage like ER stress and apoptosis, is also still unclear. To explore how asynuclein could play a critical role in Mn toxicity, experiment was carried out on recombinant adenoviral vector containing human $\alpha$-synuclein cDNA and non- specific recombinant adenoviral 
vector of $\alpha$-synuclein cDNA to clarify the mechanism of Mn toxicity.

To find the relationship between $\alpha$-synuclein aggregation and ER stress, we explored $\alpha$ synuclein aggregation induced by Mn (Figures 4, 5 and 6). Some studies have illustrated the association between pathological $\alpha$-synuclein and neuron cell death remained so far correlative [16]. However, the experimental results showed that recombinant adenoviral vector containing human a-synuclein cells demonstrated significantly decreased cell viability in vitro than non-specific recombinant adenoviral vector cells, suggesting a-synuclein induced cell toxicity. As the time and the dose of $\mathrm{Mn}$ exposure increased, a-synuclein gradually aggregated in vitro (Figure 5). Chronically exposed to $\mathrm{Mn}$, alpha synuclein aggregated in neurons and glial cells in vivo [23]. This suggests that $\alpha$-synuclein is associated with neuron cell death during acute or chronic exposure of $\mathrm{Mn}$. Whereas a previous study suggested that the molecular chaperone GRP-78 played a neuroprotective role in $\alpha$-synuclein induced PD-like neurodegeneration [24].

The data would demonstrate that GRP-78 could play an anti-protective role in it, as $\alpha$-synuclein increased cell toxicity followed by activating more GRP-78 expression as well as IRE-1 $\alpha$, p-elF-2 $\alpha$, and elF-2 $\alpha$, leading to the activation of ER stress (Figure 6A). CHOP is a pro-apoptotic protein and CHOP transcription is regulated by ER stress through UPR pathways [25]. Caspase 3 functioned as a dominant role in the apoptotic cells via an extrinsic pathway [20]. Recombinant adenoviral vector containing human $\alpha$-synuclein expressed more $\mathrm{CHOP}$ and caspase 3 protein than non - specific recombinant adenoviral vector (Figure 6B). These data suggest that $\alpha-$ synuclein activated ER stress mediators associated with IRE-1 $\alpha, \mathrm{p}-\mathrm{elF}-2 \alpha$ and elF-2 $\alpha$ pathway, leading to apoptosis (Figure 6).

\section{CONCLUSION}

$\mathrm{Mn}$ is a risk factor for diseases associated with $\alpha$ synuclein accumulation. Furthermore, $\alpha$ synuclein accumulation is associated with apoptosis via ER stress induced by $\mathrm{Mn}$, leading to Mn-induced neurotoxicity.

\section{DECLARATIONS}

\section{Acknowledgement}

This work was supported by grants from the National Research Foundation of Korea (NRF) (Grant no. 2015R1A1A13001849)

\section{Conflict of interest}

No conflict of interest is associated with this work

\section{Contribution of authors}

We declare that this work was done by the authors named in this article and all liabilities pertaining to claims relating to the content of this article will be borne by the authors. $\mathrm{H}$ Yoon, $\mathrm{GH}$ Lee and HJ Chae who conceived and designed this study. H Yoon, GH Lee, SJ Lee and B Li who collected and analysed the data. SJ Lee provided conceptual technical guidance. $\mathrm{H}$ Yoon and $\mathrm{GH}$ Lee wrote the manuscript, while $\mathrm{HJ}$ Chae has reviewed it. Hyonok Yoon and Geum Hwa Lee contributed equally to the work. Finally, all authors read and approved the manuscript for publication.

\section{REFERENCES}

1. Wales $P$, Pinho $R$, Lazaro DF, Outeiro TF. Limelight on alpha-synuclein: pathological and mechanistic implications in neurodegeneration. J Parkinsons Dis 2013; 3: 415-459. doi:10.3233/JPD-130216

2. Giasson BI, Uryu K, Trojanowski JQ, Lee VM. Mutant and wild type human alpha-synucleins assemble into elongated filaments with distinct morphologies in vitro. $J$ Biol Chem 1999; 274: 7619-7622.

3. Ltic $S$, Perovic M, Mladenovic A, Raicevic N, Ruzdijic $S$, Rakic L, Kanazir S. Alpha-synuclein is expressed in different tissues during human fetal development. J Mol Neurosci 2004; 22: 199-204.

4. McLean PJ, Kawamata $H$, Ribich $S$, Hyman BT. Membrane association and protein conformation of alpha-synuclein in intact neurons. Effect of Parkinson's disease-linked mutations. J Biol Chem 2000; 275: 88128816.

5. Kokhan VS, Afanasyeva MA, Van'kin Gl. alpha-Synuclein knockout mice have cognitive impairments. Behav Brain Res 2012; 231: 226-230. doi:10.1016/j.bbr.2012.03.026

6. Diao J, Burre J, Vivona S, Cipriano DJ, Sharma $M$, Kyoung M, Sudhof TC, Brunger AT. Native alphasynuclein induces clustering of synaptic-vesicle mimics via binding to phospholipids and synaptobrevin2/VAMP2. Elife 2013; 2: e00592. doi:10.7554/eLife.00592

7. Zaltieri M, Grigoletto J, Longhena F, Navarria L, Favero G, Castrezzati S, Colivicchi MA, Della Corte L, Rezzani $R$, Pizzi $M$, et al. alpha-synuclein and synapsin III cooperatively regulate synaptic function in dopamine neurons. $J$ Cell Sci 2015; 128: 2231-2243. doi:10.1242/jcs.157867

8. Jankovic J. Parkinson's disease: clinical features and diagnosis. J Neurol Neurosurg Psychiatry 2008; 79: 368-376. doi:10.1136/jnnp.2007.131045 
9. de Lau LM, Breteler MM. Epidemiology of Parkinson's disease. Lancet Neurol 2006; 5: 525-535. doi:10.1016/S1474-4422(06)70471-9

10. Yoon H, Lee GH, Kim DS, Kim KW, Kim HR, Chae HJ. The effects of 3,4 or 5 amino salicylic acids on manganese-induced neuronal death: ER stress and mitochondrial complexes. Toxicol In Vitro 2011; 25: 1259-1268. doi:10.1016/j.tiv.2011.04.002

11. Yoon H, Kim DS, Lee GH, Kim KW, Kim HR, Chae HJ. Apoptosis Induced by Manganese on Neuronal SK-NMC Cell Line: Endoplasmic Reticulum (ER) Stress and Mitochondria Dysfunction. Environ Health Toxicol 2011; 26: e2011017. doi:10.5620/eht.2011.26.e2011017

12. Lee HJ, Shin SY, Choi C, Lee YH, Lee SJ. Formation and removal of alpha-synuclein aggregates in cells exposed to mitochondrial inhibitors. J Biol Chem 2002; 277: 5411-5417. doi:10.1074/jbc.M105326200

13. Bowman AB, Kwakye GF, Herrero Hernandez E, Aschner $M$. Role of manganese in neurodegenerative diseases. $J$ Trace Elem Med Biol 2011; 25: 191-203. doi:10.1016/j.jtemb.2011.08.144

14. Lind KR, Ball KK, Cruz NF, Dienel GA. The unfolded protein response to endoplasmic reticulum stress in cultured astrocytes and rat brain during experimental diabetes. Neurochem Int 2013; 62: 784-795. doi:10.1016/j.neuint.2013.02.009

15. Roussel BD, Kruppa AJ, Miranda E, Crowther DC, Lomas $D A$, Marciniak SJ. Endoplasmic reticulum dysfunction in neurological disease. Lancet Neurol 2013; 12: 105-118. doi:10.1016/S1474-4422(12)70238-7

16. Mercado G, Valdes P, Hetz C. An ERcentric view of Parkinson's disease. Trends Mol Med 2013; 19: 165175. doi:10.1016/j.molmed.2012.12.005

17. Yadav RK, Chae SW, Kim HR, Chae HJ. Endoplasmic reticulum stress and cancer. J Cancer Prev 2014; 19: 75-88. doi:10.15430/JCP.2014.19.2.75

18. Alnemri ES, Livingston DJ, Nicholson DW, Salvesen G, Thornberry NA, Wong WW, Yuan J. Human ICE/CED-3 protease nomenclature. Cell 1996; 87: 171.
19. Ghavami S, Hashemi M, Ande SR, Yeganeh B, Xiao W, Eshraghi M, Bus CJ, Kadkhoda K, Wiechec E, Halayko $A J$, et al. Apoptosis and cancer: mutations within caspase genes. J Med Genet 2009; 46: 497-510. doi:10.1136/jmg.2009.066944

20. Perry DK, Smyth MJ, Stennicke HR, Salvesen GS, Duriez $P$, Poirier GG, Hannun YA. Zinc is a potent inhibitor of the apoptotic protease, caspase-3. A novel target for zinc in the inhibition of apoptosis. J Biol Chem 1997; 272: 18530-18533.

21. Cai T, Yao T, Zheng G, Chen Y, Du K, Cao Y, Shen $X$, Chen J, Luo W. Manganese induces the overexpression of alpha-synuclein in PC12 cells via ERK activation. Brain Res 2010; 1359: 201-207. doi:10.1016/j.brainres.2010.08.055

22. Xu B, Wang F, Wu SW, Deng Y, Liu W, Feng S, Yang $T Y, X u Z F$. alpha-Synuclein is involved in manganeseinduced ER stress via PERK signal pathway in organotypic brain slice cultures. Mol Neurobiol 2014; 49: 399-412. doi:10.1007/s12035-013-8527-2

23. Guilarte TR. APLP1, Alzheimer's-like pathology and neurodegeneration in the frontal cortex of manganeseexposed non-human primates. Neurotoxicology 2010; 31: 572-574. doi:10.1016/j.neuro.2010.02.004

24. Gorbatyuk MS, Shabashvili A, Chen W, Meyers C, Sullivan LF, Salganik M, Lin JH, Lewin AS, Muzyczka N, Gorbatyuk OS. Glucose regulated protein 78 diminishes alpha-synuclein neurotoxicity in a rat model of Parkinson disease. Mol Ther 2012; 20: 1327-1337. doi:10.1038/mt.2012.28

25. Ohri SS, Maddie MA, Zhang Y, Shields CB, Hetman M, Whittemore SR. Deletion of the pro-apoptotic endoplasmic reticulum stress response effector $\mathrm{CHOP}$ does not result in improved locomotor function after severe contusive spinal cord injury. J Neurotrauma 2012; 29: 579-588. doi:10.1089/neu.2011.1940 